\title{
Review
}

Ruud G. Nijman*

\section{The impact of the COVID-19 pandemic on child health}

https://doi.org/10.1515/labmed-2021-0128

Received September 14, 2021; accepted September 23, 2021; published online October 12, 2021

Abstract: Most Severe Acute Respiratory Syndrome Coronavirus 2 (SARS-CoV-2) infections in children are mild or asymptomatic. Severe Coronavirus Disease 2019 (COVID-19) in children is infrequent. An estimated $0.3-1.3 \%$ of children with SARS-CoV-2 infection were admitted to hospital, and of these $13-23 \%$ needed critical care. SARS-CoV-2 related deaths were very rare in children, estimated at 2 per million. The vast majority of admitted children had one of shortness of breath, fever, and cough, but atypical symptoms are more common in children. Cases of Multisystem Inflammatory Syndrome in Children (MIS-C) have been linked to SARS-CoV-2 infection. Cardinal symptoms include prolonged fever, clinical signs of inflammation, gastro-intestinal symptoms, and cardiac dysfunction. Twenty two to $80 \%$ of patients with MIS-C needed critical care; mortality of MIS-C is around $2 \%$. Six to $24 \%$ of children with MIS-C had coronary artery dilatation or cardiac aneurysms. Equipoise still exists between first-line treatment with immunoglobulins and steroids. Outcomes for children with MIS-C are generally very good in those recognised early and started on appropriate treatment. Vaccination schemes for children are rapidly expanding, with the benefits of preventing severe COVID-19 disease and MIS-C and reducing community transmission outweighing the risks of adverse events of, amongst others, myocarditis temporally related to COVID-19 vaccination in children and young adults. The imposed social distancing measures reduced the overall number of children with acute illness or injury presenting to urgent and emergency care facilities worldwide. No clear signal was seen that large numbers of

\footnotetext{
*Corresponding author: Dr. Ruud G. Nijman PhD, Department of Infectious Disease, Section of Paediatric Infectious Diseases, Imperial College London, London, UK; and Centre for Paediatrics and Child Health, Imperial College London, London, UK, E-mail: r.nijman@imperial.ac.uk. https://orcid.org/0000-0001-96718161
}

Ә Open Access. ( 2021 Ruud G. Nijman, published by De Gruyter. (6c) BY License. children had a delayed presentation to emergency care departments with a serious illness. The social distancing measures negatively impacted the mental health of children.

Keywords: child; child health; COVID-19; multisystem inflammatory syndrome in children (MIS-C); SARS-CoV-2; social distancing measures.

\section{Introduction}

Early data from China already signalled low numbers of children presenting to hospitals with severe respiratory Illness during the initial Coronavirus Disease 2019 (COVID-19) outbreak [1]. Despite this, many health facilities dealing with acutely unwell children and young people prepared for potentially large numbers of unwell children infected with Severe Acute Respiratory Syndrome Coronavirus 2 (SARS-CoV-2). Yet, this never materialised and quite the opposite was true with very few children presenting to urgent and emergency care facilities [2]. This review will cover topics related to SARS-CoV-2 infection in children and the wider impact of the COVID-19 pandemic on child health.

\section{Children with COVID-19}

The vast majority of SARS-CoV-2 infections in children are asymptomatic or mild [1,3-6]. Testing strategies for SARS-CoV-2 varied between countries and in time [7], and hence it will be difficult to determine the true rate of children infected with SARS-CoV-2 developing more severe acute illness with the need of being admitted to hospital. A large-scale multinational cohort study, the CHARYBDIS study, using routinely collected data from the United States, Europe, and Asia found that $0.3-1.3 \%$ of children diagnosed with COVID-19 were admitted to hospital in the period between January and June 2020 [8]. Based on population seroprevalence studies from the United Kingdom (UK) this percentage might be as low as $100-400$ per 
million children during the second phase of the COVID-19 pandemic [9-11].

Typical symptoms of fever (69\%), cough (48\%) and shortness of breath (23\%) were present amongst hospitalised children 18 years and under who tested positive for SARS-CoV-2, according to data from the International Severe Acute Respiratory and emerging Infection Consortium (ISARIC), a prospective multinational observational study; with $85 \%$ of admitted children having at least one of these [12]. Atypical symptoms occurred more often in hospitalised children than adults. For example, children regularly present with gastro-intestinal features, including some serious conditions such as intussusception [13-19]. Additionally, studies reported up to $40 \%$ positive tests in children admitted without any COVID-19 disease related symptoms, mainly as a result of routine admission or preoperative screening in the more recent stages of the pandemic [20-22]. In general, children and young people with severe neuro-disabilities, Down's Syndrome, underlying conditions resulting in immunosuppression, and children with learning disabilities were at higher risk for severe COVID-19 disease [4, 11].

In the UK data from the ISARIC cohort, $18 \%$ (116/632) of hospitalised children were admitted to critical care. This number was replicated in the study by the TBNet research group, with 13\% (48/363) of hospitalised children needing critical care across European hospitals in early 2020 [3]. A study linking the UK National Child Mortality Database and Public Health England testing data identified children aged 18 years and under who died with a positive SARS-CoV-2 test between March 2020 and February 2021. In this study, a total of 3,105 childhood deaths were reported and, of these, 61 deaths (1.9\%) tested positive for SARS-CoV-2; 25 of these were caused by SARS-CoV-2 with another three deaths related to Multisystem Inflammatory Syndrome in Children (MIS-C) temporally related to SARS-CoV-2 infection [23]. The 25 children who died of SARS-CoV-2 equate to a mortality rate of 2 per million children.

A recent increase in paediatric COVID-19 related hospital admissions in the United States (US) is believed to be related more to the high prevalence in the community of the SARS-CoV-2 Delta variant, and its increased ability for transmission, rather than an increase in severity [24, 25]. For example, in the COVID-NET study from the US that included data from over 250 acute-care US hospitals in 14 States, the median duration of admission of children was two days (IQR 1-4 days) for the period June 20th 2021 - July 31st 2021; and of these, $23.2 \%$ of admitted children needed critical care, and $1.8 \%$ died during hospitalisation [25]. There was no clear signal that admitted children during this period were more severely unwell than the preceding period between March 1st 2020 and June 19th 2021.

\section{MIS-C}

Early in the COVID-19 pandemic, a new inflammatory condition was identified in children, occurring some 2-6 weeks after initial, often asymptomatic, SARS-CoV-2 infection, called the Multisystem Inflammatory Syndrome in Children (MIS-C) [26-32]. A year into the COVID-19 pandemic, cases of MIS-C have been described globally [33], and it is now believed that MIS-C is a true novel immunopathogenic illness [31, 34, 35]. Importantly, the incidence of MIS-C is rare: for example, between March 2020 and July 2020 there were a total of 449 cases of MIS-C in children aged $<16$ years in the UK [11]. Although children of all ages can be affected, it is more frequent in the adolescent age group [28]. Similarly, boys appear affected more often, as well as children from ethnic minorities and more deprived backgrounds, likely reflecting increased transmission and higher seroprevalence rates in these groups.

Case definitions of MIS-C were issued by the World Health Organisation (WHO), Center for Disease Control and Hygiene (CDC), and Royal College of Paediatrics and Child Health (RCPCH) in April - May 2020. These, although differing slightly (Table 1) [36-38], all included criteria of 1) persistent fever, 2) clinical signs and biochemical profiles reflecting ongoing inflammation, 3) multiorgan involvement including cardiac dysfunction, 4) the absence of other reasonable explanations of the acute illness, and 5) evidence of a preceding SARS-CoV-2 infection or exposure. Guidance was subsequently issued to support frontline clinicians in the early recognition and management of children at risk of MIS-C [39].

Typically, children with MIS-C present with prolonged fever, clinical signs of inflammation (e.g. conjunctivitis, rash, and oral mucosal changes), gastro-intestinal symptoms, and cardiac dysfunction [27, 28, 40]. Concerningly, $6-24 \%$ of children with MIS-C had coronary artery dilatation or cardiac aneurysms [33, 41-44]. MIS-C mimicking appendicitis [45] and other serious abdominal pathology [46] have been described, as well as children with neurological involvement [47].

Clinically, MIS-C can be difficult to differentiate from Kawasaki Disease, a childhood medium artery vasculitis, or Toxic Shock Syndrome [48, 49]. However, each of these diagnoses appear to have distinct biochemical patterns. Notably, children with MIS-C had higher white blood cell count, neutrophil count, ferritin and CRP, as well as more 


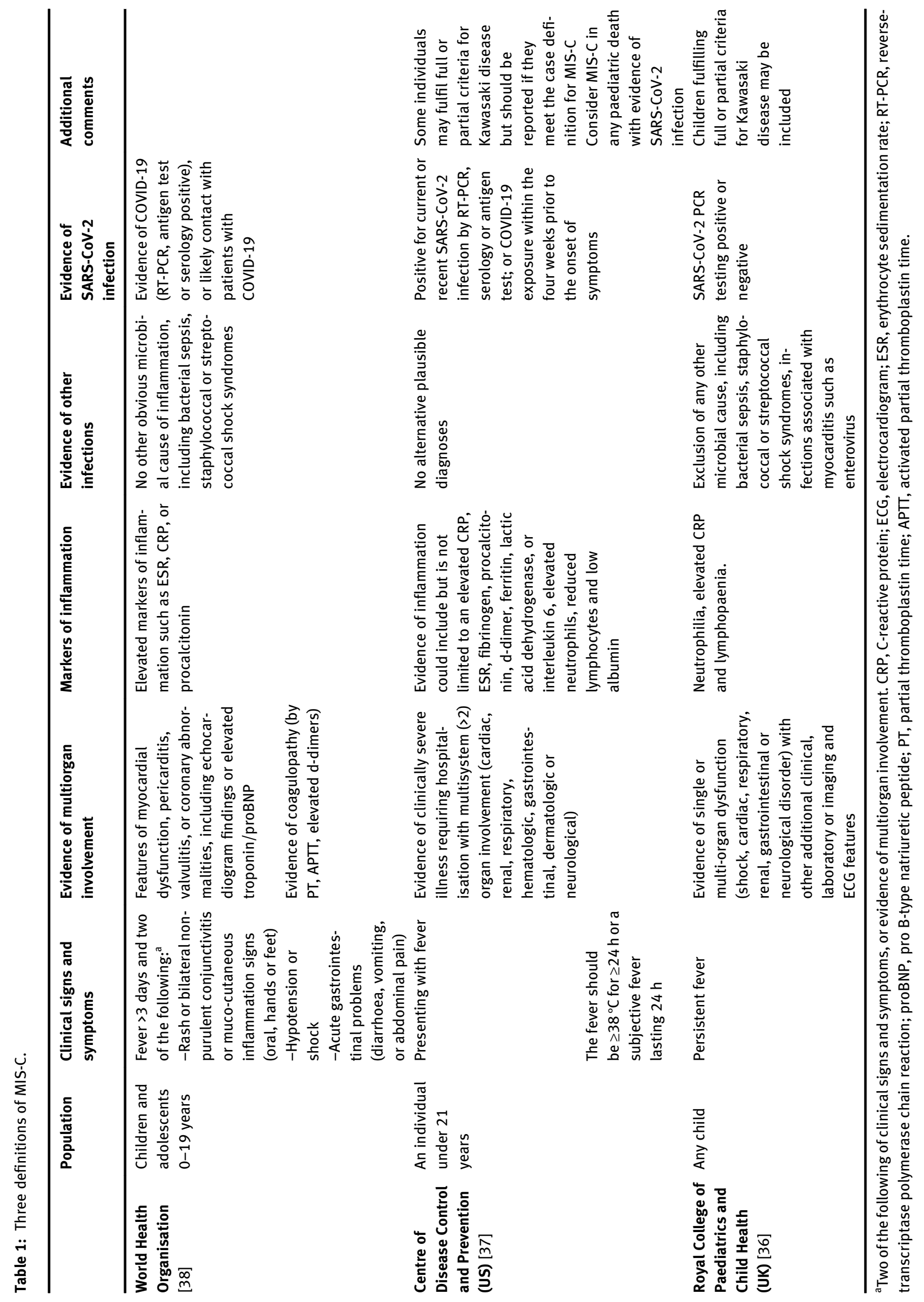


profound lymphopaenia and thrombocytopaenia compared with Kawasaki Disease [31, 50, 51]. Increased levels of D-dimers, B-type natriuretic peptide, troponin, and proinflammatory interleukines have also been linked to MIS-C $[35,52,53]$. A novel point-of-care diagnostic test for diagnosing MIS-C using RNA sequencing, developed by the multinational DIAMONDS research consortium, is showing initial encouraging results [54-56].

Whereas using immunoglobulins as first line treatments in Kawasaki Disease and Toxic Shock Syndrome are well established [57, 58], equipoise still exists between immunoglobulins and steroids for the treatment of MIS-C $[33,42,59]$. Taking the costs and global scarcity of immunoglobulins into account, the option of using steroids as first line treatment for MIS-C would have important implications, in particular in low- and middle-income countries where immunoglobulins might not be readily available. In observational studies, both immunoglobulins and steroids were effective in switching off the inflammatory process in nearly all cases, with swift cessation of fever and marked reduction of inflammatory markers [33, 42, 59]. The RECOVERY trial, which has previously successfully evaluated treatments for adults with COVID-19, is expected to present the results of the first randomised treatment trial for immunoglobulins vs. steroids in children with MIS-C [60]. Immunomodulation with biologicals, such as inhibitors of IL-1, IL-6, and TNF, have also been suggested in MIS-C. Other treatment considerations in MIS-C include starting aspirin and heparins. Because of the overlap in clinical presentation with toxic shock syndrome, early administration of broad-spectrum antibiotics will be important. Cardiac dysfunction should be recognised promptly, with diagnostic roles for troponin and B-type natriuretic peptide levels in blood, electrocardiogram and echocardiogram, and early initiation of inotropic support should be considered in addition to careful fluid resuscitation.

In initial cohorts, $40-80 \%$ of children with MIS-C were admitted to critical care units [29-31, 42, 61]. Across studies, approximately $2 \%$ of patients with MIS-C died [2931, 42, 61] The Best Available Treatment Study, including cases from 34 countries between June 2020 and February 2021 reported fewer children needing critical care, with $22 \%$ (138/614) of children requiring organ support defined as inotropic support, mechanical ventilation or extracorporeal membrane oxygenation support [33]. This lower rate of admission to critical care units supports the observation that MIS-C has a wide clinical spectrum of severity. Possibly, it also reflects improved recognition and management over time. Outcomes for children with MIS-C appear good in those where the diagnosis was made early and appropriate treatment was started [62].

\section{Vaccinating children}

Different strategies have been deployed around the world to vaccinate children and young people against SARS-CoV-2 [63]. The European Union, UK, and the US currently advocate vaccinations for those aged 12 years and over [11, 64,65 ], with roll out of vaccinations for younger children expected soon. As the risks of severe COVID-19 and MIS-C are very small in children and as vaccines are typically administered in healthy individuals, these risks need to be balanced against the benefits of being vaccinated against SARS-CoV-2 and the potential risks associated with such a vaccination. Cases of myocarditis in children and young adults following mRNA vaccines have caused concern, and although many of these cases appear mild and transient [66, 67], some have needed hospital admission, and even admission to intensive care and some deaths have been reported [66, 68-70]. Mostly, cases of myocarditis were temporally linked to the second vaccination, yet a causal relationship, although suspected, has not been proven [71]. Additionally, there is the important aspect of vaccines reducing household and community spread [72].

\section{Long COVID}

Until now, the prevalence of post-acute or long COVID syndrome has only played a minor role in the decisionmaking processes around mitigation measures against SARS-CoV-2. Post-viral infection syndromes have been described previously [73, 74]. Although believed to be less common than in adults, early studies observed persisting symptoms after SARS-COV-2 infection in a high proportion of children [75-78]. Yet, available data in children largely lacked appropriate control groups amongst other design flaws. The prospective observational CLoCK study has thusfar provided most reliable evidence, matching children with and without positive SARS-CoV-2 polymerase chain reaction results and looking at their symptoms at time of test results and three months later [79]. Children with positive SARS-CoV-2 PCR test result more often had a single (35.4 vs. $8.3 \%$ ) or $3+$ symptoms (30.6 vs. $6.2 \%$ ) at the time of testing than those with a negative result; somewhat surprising, at three months the presence of physical symptoms was higher for both children with a positive test as well as for children with a negative test: $66.5 \%$ (test positive) vs. $53.5 \%$ (test negative) for a single symptom, and $30.3 \%$ (test positive) vs. $16.2 \%$ (test negative) for 3+ symptoms. Symptoms of tiredness, headache, and shortness of breath persisted most often at three months. Scores 
for mental health and well-being were the same between those testing positive and those testing negative. Those who tested positive were more likely to disclose issues with mobility, doing usual activities, and pain/discomfort on quality-of-life scores. In general, there appears to be a postviral syndrome with persisting symptoms in children with a previous SARS-CoV-2 infection, considerably limiting daily functioning in a small group of children. However, similar symptoms are also seen in children without a prior SARS-CoV-2 infection, in whom symptoms were potentially related to another viral infection or explained by the impact of COVID-19 social distancing measures.

\section{Social distancing measures and the impact on child health}

Efforts to contain SARS-CoV-2 spread in the community have differed between countries, but, on the whole, highincome countries had some social distancing measures in place at one or more moments over the last year. Social distancing measures varied from advice on hand hygiene, hand washing and physical distancing, to full lockdown of entire societies and blanket 'Stay at home' orders. In many countries schools were closed for prolonged periods of time. These social distancing measures greatly reduced the number of children presenting to emergency departments for acute illness or injury [80-84]. For example, there was a notable reduction of respiratory tract infections over the winter of 2020-2021 [85]. Interestingly, with the relaxation of social distancing measures, and with children returning to schools, familiar childhood infections returned, resulting in out-of-season outbreaks of respiratory viruses such as respiratory syncytial virus [86-88].

Concerns were raised about more severe presentations to hospitals as a result of delays in healthcare seeking behaviour and changes in how to access healthcare [89-92]. In the UK this prompted the RCPCH to issue a national alert with information for parents on when and how to access urgent and emergency care during the first phase of the COVID-19 pandemic [93]. However, Roland et al. concluded that delays in presentation were infrequent, and that only a minority (six out of $51(11.8 \%)$ ) of children with a potential delay in presentation were subsequently admitted to one of seven hospitals [94]. Studies on delays in presentations for appendicitis [95, 96] and testicular torsion [97-100] reached contradictory conclusions. No increase in overall childhood mortality was noted over the first period of the COVID-19 pandemic in the UK [101].
The social distancing measures had significant effects on many aspects of child health. For example, increased ED presentations for child abuse and neglect were observed [102, 103], some of which might have reflected changes in healthcare pathways [104]. Similarly, although overall numbers of traumatic injuries reduced, there was an increase in non-accidental injuries [105] and injuries sustained at home [106]. Perhaps most alarming has been the large increase in mental health issues and eating disorders [107-110].

Finally, Unsworth et al. first detected an increase of new onset type 1 diabetes in children and a possible association with SARS-CoV-2 in the UK [111]. Similarly, Salmi et al. found an increase in children registered to the national diabetes database in Finland early in the COVID-19 pandemic [112]. By now, evidence is mounting to show the role of SARS-CoV-2 in the pathogenesis of new onset diabetes mellitus [113, 114]. Moreover, other viruses, such as the group of enteroviruses, have previously been linked to type 1 diabetes mellitus [115]. However, other studies did not find an increase in new onset diabetes in children and young people, nor a change in severity at time of first presentation [116, 117]. Future research will need to provide more definitive evidence of the association between SARS-CoV-2 and new onset diabetes.

\section{Conclusions}

As severe COVID-19 disease is rare in children, societies and governments have focussed on adult COVID-19 disease for the majority of the COVID-19 pandemic. The child's voice has largely been unheard throughout most of the pandemic. However, many aspects of child health have been influenced by the COVID-19 pandemic and mitigation efforts. School closures and other social distancing measures affected vulnerable children from disadvantaged families the worst, and it worryingly impacted the mental health of children at a large scale. Overall, there was a marked decrease in acute illness and injuries in children owing to the social distancing measures, providing insights on how we can reduce the burden of childhood disease in future. Moreover, there has not been a clear signal that the COVID-19 pandemic resulted in changed health seeking behaviour leading to large numbers of children with delayed presentations of serious illness. Vaccination programmes for children are accelerating, contributing to reducing COVID-transmission in the community, as well as preventing cases of children with severe COVID-19, MIS-C, or long Covid. The controversies about the need to vaccinate 
children and about the safe reopening of schools have, for now, put the children at the forefront of this COVID-19 pandemic.

Research funding: RN was awarded a National Institute for Health Research academic clinical lectureship award (2018-021-007).

Author contributions: $\mathrm{RN}$ is the sole author of this manuscript and accepts responsibility for the entire content of this manuscript and approves its submission.

Competing interests: Author states no conflict of interest. Informed consent: Not applicable.

Ethical approval: Not applicable.

\section{References}

1. Lu X, Zhang L, Du H, Zhang J, Li YY, Qu J, et al. SARS-CoV-2 infection in children. N Engl J Med 2020;382:1663-5.

2. Bressan S, Buonsenso D, Farrugia R, Parri N, Oostenbrink R, Titomanlio L, et al. Preparedness and response to pediatric COVID-19 in European emergency departments: a survey of the REPEM and PERUKI networks. Ann Emerg Med 2020;76: 788-800.

3. Götzinger F, Santiago-García B, Noguera-Julián A, Lanaspa M, Lancella L, Calò Carducci FI, et al. COVID-19 in children and adolescents in Europe: a multinational, multicentre cohort study. Lancet Child Adolesc Health 2020;4:653-61.

4. Swann OV, Holden KA, Turtle L, Pollock L, Fairfield C), Drake TM, et al. Clinical characteristics of children and young people admitted to hospital with covid-19 in United Kingdom: prospective multicentre observational cohort study. BMJ 2020; 370:m3249.

5. Parri N, Lenge M, Buonsenso D. Children with covid-19 in pediatric emergency departments in Italy. N Engl J Med 2020; 383:187-90.

6. DeBiasi RL, Song X, Delaney M, Bell M, Smith K, Pershad J, et al. Severe coronavirus disease-2019 in children and young adults in the Washington, DC, metropolitan region. J Pediatr 2020;223: 199-203.e1.

7. European Centre for disease prevention and Control. COVID-19 testing strategies and objectives key messages [Internet]. https://www.ecdc.europa.eu/sites/default/files/documents/ TestingStrategy_Objective-Sept-2020.pdf [Accessed 7 Sep 2021].

8. Duarte-Salles T, Vizcaya D, Pistillo A, Casajust P, Sena AG, Lai $\mathrm{LYH}$, et al. Thirty-day outcomes of children and adolescents with COVID-19: an international experience. Pediatrics 2021;148: e2020042929.

9. Office for National Statistics. Coronavirus (COVID-19) infection survey, antibody and vaccination data, UK [Internet]:1-15. https://www.ons.gov.uk/peoplepopulationandcommunity/ healthandsocialcare/conditionsanddiseases/bulletins/ coronaviruscovid19infectionsurveyantibodyand vaccinationdatafortheuk/latest [Accessed 7 Sep 2021].

10. NHS. Vaccinations in the UK / coronavirus in the UK [Internet]. Gov.Uk; 2021. https://coronavirus.data.gov.uk/details/ vaccinations [Accessed 7 Sep 2021].
11. GOV.UK. Independent report: JCVI statement on COVID-19 vaccination of children and young people aged 12 to 17 years: 15 July 2021 [Internet]. Gov.Uk; 2021. https://www.gov.uk/ government/publications/covid-19-vaccination-of-childrenand-young-people-aged-12-to-17-years-jcvi-statement/jvcistatement-on-covid-19-vaccination-of-children-and-youngpeople-aged-12-to-17-years-15-july-2021 [Accessed 7 Sep 2021].

12. ISARIC Clinical Characterisation Group. COVID-19 symptoms at hospital admission vary with age and sex: results from the ISARIC prospective multinational observational study. Infection 2021;49:889-905.

13. Puoti MG, Rybak A, Kiparissi F, Gaynor E, Borrelli O. SARS-CoV-2 and the gastrointestinal tract in children. Front Pediatr 2021;9: 617980.

14. Moazzam Z, Salim A, Ashraf A, Jehan F, Arshad M. Intussusception in an infant as a manifestation of COVID-19. J Pediatr Surg Case Rep 2020;59:101533.

15. Cai X, Ma Y, Li S, Chen Y, Rong Z, Li W. Clinical characteristics of 5 COVID-19 cases with non-respiratory symptoms as the first manifestation in children. Front Pediatr 2020;8:258.

16. Martínez-Castaño I, Calabuig-Barbero E, Gonzálvez-Piñera J, López-Ayala JM. COVID-19 infection is a diagnostic challenge in infants with ileocecal intussusception. Pediatr Emerg Care 2020;36:e368.

17. Bazuaye-Ekwuyasi EA, Camacho AC, Saenz Rios F, Torck A, Choi WJ, Aigbivbalu EE, et al. Intussusception in a child with COVID-19 in the USA. Emerg Radiol 2020;27:761-4.

18. Makrinioti H, MacDonald A, Lu X, Wallace S, Jobson M, Zhang F, et al. Intussusception in 2 children with severe acute respiratory syndrome coronavirus-2 infection. J Pediatr Infect Dis Soc 2020; 9:504-6.

19. Giovanni JE, Hrapcak S, Melgar M, Godfred-Cato S. Global reports of intussusception in infants with SARS-CoV-2 infection. Pediatr Infect Dis I 2020;40:35-6.

20. Brookman S, Cook J, Zucherman M, Broughton S, Harman K, Gupta A. Effect of the new SARS-CoV-2 variant B.1.1.7 on children and young people. Lancet Child Adolesc Health 2021; 5:e9-10.

21. Webb NE, Osburn TS. Characteristics of hospitalized children positive for SARS-CoV-2: experience of a large center. Hosp Pediatr 2021;11:e133-41.

22. Swann OV, Pollock L, Holden KA, Munro APS, Bennet A, Williams TC, et al. ISARIC: comparison of children and young people admitted with SARS-CoV-2 across the UK in the first and second pandemic waves - prospective multicentre observational cohort study, 9 September 2021 [Internet]. https://www.gov.uk/government/publications/isariccomparison-of-children-and-young-people-admitted-with-sarscov-2-across-the-uk-in-the-first-and-second-pandemic-wavesprospective-multicentr [Accessed 20 Sep 2021].

23. Smith C, Odd D, Harwood R, Ward J, Linney M, Clark M, et al. Deaths in children and young people in England following SARS-CoV- 2 infection during the first pandemic year: a national study using linked mandatory child death reporting data. medRxiv 2021;2021:21259779.

24. Siegel DA, Reses HE, Cool AJ, Shapiro CN, Hsu J, Boehmer TK, et al. Trends in COVID-19 cases, emergency department visits, and hospital admissions among children and adolescents aged 0-17 years - United States, August 2020-August 2021. MMWR Morb Mortal Wkly Rep 2021;70:1249-54. 
25. Delahoy MJ, Ujamaa D, Whitaker M, O'Halloran A, Anglin O, Burns E, et al. Hospitalizations associated with COVID-19 among children and adolescents - COVID-NET, 14 states, March 1, 2020-August 14, 2021. MMWR Morb Mortal Wkly Rep 2021;70: $1255-60$.

26. Jones VG, Mills M, Suarez D, Hogan CA, Yeh D, Bradley Segal J, et al. COVID-19 and Kawasaki disease: novel virus and novel case. Hosp Pediatr 2020;10:537-40.

27. Riphagen S, Gomez X, Gonzalez-Martinez C, Wilkinson N, Theocharis P. Hyperinflammatory shock in children during COVID-19 pandemic. Lancet 2020;395:1607-8.

28. Verdoni L, Mazza A, Gervasoni A, Martelli L, Ruggeri M, Ciuffreda $M$, et al. An outbreak of severe Kawasaki-like disease at the Italian epicentre of the SARS-CoV-2 epidemic: an observational cohort study. Lancet 2020;395:1771-8.

29. Dufort EM, Koumans EH, Chow EJ, Rosenthal EM, Muse A, Rowlands J, et al. Multisystem inflammatory syndrome in children in New York state. N Engl J Med 2020;383:347-58.

30. Feldstein LR, Rose EB, Horwitz SM, Collins JP, Newhams MM, Son MBF, et al. Multisystem inflammatory syndrome in U.S. children and adolescents. N Engl J Med 2020;383:334-46.

31. Whittaker E, Bamford A, Kenny J, Kaforou M, Jones CE, Shah P, et al. Clinical characteristics of 58 children with a pediatric inflammatory multisystem syndrome temporally associated with SARS-CoV-2. J Am Med Assoc 2020;324:259-69.

32. Jiang L, Tang K, Levin M, Irfan O, Morris SK, Wilson K, et al. COVID-19 and multisystem inflammatory syndrome in children and adolescents. Lancet Infect Dis 2020;20:e276-88.

33. McArdle AJ, Vito O, Patel H, Seaby EG, Shah P, Wilson C, et al. Treatment of multisystem inflammatory syndrome in children. $\mathrm{N}$ Engl J Med 2021;385:11-22.

34. Consiglio CR, Cotugno N, Sardh F, Pou C, Amodio D, Rodriguez L, et al. The immunology of multisystem inflammatory syndrome in children with COVID-19. Cell 2020;183:968-81.e7.

35. Carter MJ, Fish M, Jennings A, Doores KJ, Wellman P, Seow J, et al. Peripheral immunophenotypes in children with multisystem inflammatory syndrome associated with SARS-CoV-2 infection. Nat Med 2020;26:1701-7.

36. RCPCH. Guidance: paediatric multisystem inflammatory syndrome temporally associated with COVID-19, vol 57. London, UK; Royal College of Paediatrics and Child Health. https://www.rcpch.ac.uk/ resources/guidance-paediatric-multisystem-inflammatorysyndrome-temporally-associated-covid-19 [Accessed 6 May 2020].

37. Outreach C. Multisystem inflammatory syndrome in children (MIS-C) associated with coronavirus disease 2019 (COVID-19). 2020. p. Centers for Disease Control and Preventian. https://emergency.cdc.gov/han/2020/han00432.asp [Accessed 6 May 2020].

38. Jiang L, Tang K, Levin M, Irfan O, Morris SK, Wilson K, et al. COVID-19 and multisystem inflammatory syndrome in children and adolescents. Lancet Infect Dis 2020;20:e276-88.

39. Nijman RG, De Guchtenaere A, Koletzko B, Ross Russell R, Copley S, Titomanlio L, et al. Pediatric inflammatory multisystem syndrome: statement by the pediatric section of the European Society for Emergency Medicine and European Academy of Pediatrics [internet]. Front Pediatr 2020;8:490.

40. Belhadjer Z, Méot M, Bajolle F, Khraiche D, Legendre A, Abakka $\mathrm{S}$, et al. Acute heart failure in multisystem inflammatory syndrome in children in the context of global SARS-CoV-2 pandemic. Circulation 2020;142:429-36.
41. Toubiana J, Poirault C, Corsia A, Bajolle F, Fourgeaud J, Angoulvant $\mathrm{F}$, et al. Kawasaki-like multisystem inflammatory syndrome in children during the covid-19 pandemic in Paris, France: prospective observational study. BMJ 2020;369:m2094.

42. Son MBF, Murray N, Friedman K, Young CC, Newhams MM, Feldstein LR, et al. Multisystem inflammatory syndrome in children - initial therapy and outcomes. N Engl J Med 2021;385 23-34.

43. Sperotto F, Friedman KG, Son MBF, VanderPluym CJ, Newburger JW, Dionne A. Cardiac manifestations in SARS-CoV-2-associated multisystem inflammatory syndrome in children: a comprehensive review and proposed clinical approach. Eur J Pediatr 2021;180:307-22.

44. Valverde I, Singh Y, Sanchez-De-Toledo J, Theocharis $P$, Chikermane A, Di Filippo S, et al. Acute cardiovascular manifestations in 286 children with multisystem inflammatory syndrome associated with COVID-19 infection in Europe. Circulation 2021;143:21-32.

45. Tullie L, Ford K, Bisharat M, Watson T, Thakkar H, Mullassery D, et al. Gastrointestinal features in children with COVID-19: an observation of varied presentation in eight children. Lancet Child Adolesc Health 2020;4:e19-20.

46. Miller J, Cantor A, Zachariah P, Ahn D, Martinez M, Margolis KG. Gastrointestinal symptoms as a major presentation component of a novel multisystem inflammatory syndrome in children that is related to coronavirus disease 2019: a single center experience of 44 cases. Gastroenterology 2020;159:1571-4.e2.

47. Larovere KL, Riggs BJ, Poussaint TY, Young CC, Newhams MM, Maamari $M$, et al. Neurologic involvement in children and adolescents hospitalized in the United States for COVID-19 or multisystem inflammatory syndrome. JAMA Neurol 2021;78: 536-47.

48. Lee MS, Liu YC, Tsai CC, Hsu JH, Wu JR. Similarities and differences between COVID-19-related multisystem inflammatory syndrome in children and Kawasaki disease. Front Pediatr 2021;9:573.

49. Carter MJ, Shankar-Hari M, Tibby SM. Paediatric inflammatory multisystem syndrome temporally-associated with SARS-CoV-2 infection: an overview. Intensive Care Med 2021;47:90-3.

50. Bar-Meir M, Guri A, Godfrey ME, Shack AR, Hashkes PJ, Goldzweig 0 , et al. Characterizing the differences between multisystem inflammatory syndrome in children and Kawasaki disease. Sci Rep 2021;11:13840.

51. Roberts JE, Campbell JI, Gauvreau K, Lamb GS, Newburger J, Son MB, et al. Differentiating multisystem inflammatory syndrome in children: a single-centre retrospective cohort study. Arch Dis Child 2021 Jul 8. https://doi.org/10.1136/ archdischild-2021-322290 [Epub ahead of print].

52. Lee PY, Day-Lewis M, Henderson LA, Friedman KG, Lo J, Roberts JE, et al. Distinct clinical and immunological features of SARSCoV-2-induced multisystem inflammatory syndrome in children. J Clin Invest 2020;130:5942-50.

53. Kelly MS, Fernandes ND, Carr AV, Lahoud-Rahme M, Cummings BM, Chiu JS. Distinguishing features of patients evaluated for multisystem inflammatory syndrome in children. Pediatr Emerg Care 2021;37:179-84

54. Wright VJ, Herberg JA, Kaforou M, Shimizu C, Eleftherohorinou H, Shailes $\mathrm{H}$, et al. Diagnosis of Kawasaki disease using a minimal whole-blood gene expression signature. JAMA Pediatr 2018;172: e182293. 
55. Pennisi I, Rodriguez-Manzano J, Moniri A, Kaforou M, Herberg JA, Levin $M$, et al. Translation of a host blood RNA signature distinguishing bacterial from viral infection into a platform suitable for development as a point-of-care test. JAMA Pediatr 2021;175:417-9.

56. Jackson H, Calle IR, Broderick C, Habgood-Coote D, d'Souza G, Nichols S, et al. Characterisation of the blood RNA host response underpinning severity in COVID-19 patients. medRxiv [Internet] 2021 Jan 1; 2021.09.16.21263170. Available from: http:// medrxiv.org/content/early/2021/09/21/2021.09.16.21263170. abstract.

57. McCrindle BW, Rowley AH, Newburger JW, Burns JC, Bolger AF, Gewitz M, et al. Diagnosis, treatment, and long-term management of Kawasaki disease: a scientific statement for health professionals from the American Heart Association. Circulation 2017;135:e927-99.

58. Parks T, Wilson C, Curtis N, Norrby-Teglund A, Sriskandan S. Polyspecific intravenous immunoglobulin in clindamycintreated patients with streptococcal toxic shock syndrome: a systematic review and meta-analysis. Clin Infect Dis 2018;67: 1434-6.

59. Ouldali N, Toubiana J, Antona D, Javouhey E, Madhi F, Lorrot M, et al. Association of intravenous immunoglobulins plus methylprednisolone vs. immunoglobulins alone with course of fever in multisystem inflammatory syndrome in children. J Am Med Assoc 2021;325:855-64.

60. Wilkinson E. RECOVERY trial: the UK covid-19 study resetting expectations for clinical trials. BMJ 2020;369:m1626.

61. Flood J, Shingleton J, Bennett E, Walker B, Amin-Chowdhury Z, Oligbu $G$, et al. Paediatric multisystem inflammatory syndrome temporally associated with SARS-CoV-2 (PIMS-TS): prospective, national surveillance, United Kingdom and Ireland, 2020. Lancet Reg Health Eur 2021;3:100075.

62. Davies P, du Pré P, Lillie J, Kanthimathinathan HK. One-year outcomes of critical care patients post-COVID-19 multisystem inflammatory syndrome in children. JAMA Pediatr 2021 Aug 30. https://doi.org/10.1001/jamapediatrics.2021.2993 [Epub ahead of print].

63. Saxena S, Skirrow H, Wighton K. Should the UK vaccinate children and adolescents against covid-19? BMJ 2021;374: n1866.

64. Centro de Control de Enfermedades (CDC) Estados Unidos. Summary document for interim clinical considerations for use of COVID-19 vaccines currently authorized in the United States FactSheet; 2021:1-2. https://www.cdc.gov/vaccines/covid-19/ clinical-considerations/covid-19-vaccines-us.html [Accessed 7 Sep 2021].

65. European Centre for Disease Prevention and Control. Interim public health considerations for COVID-19 vaccination of adolescents in the EU/EEA key messages current status and national recommendations concerning vaccination of adolescents in the EU/EEA [Internet]. Technical Report; 2021: 1-19. https://www.ecdc.europa.eu/en/publications-data/ interim-public-health-considerations-covid-19-vaccinationadolescents-eueea [Accessed 7 Sep 2021].

66. Marshall M, Ferguson ID, Lewis P, Jaggi P, Gagliardo C, Collins JS, et al. Symptomatic acute myocarditis in 7 adolescents after pfizer-BioNTech COVID-19 vaccination. Pediatrics 2021;148: e2021052478.
67. Jain SS, Steele JM, Fonseca B, Huang S, Shah S, Maskatia SA, et al. COVID-19 vaccination-associated myocarditis in adolescents. Pediatrics 2021 Aug 13. https://doi.org/10.1542/ peds.2021-053427.

68. Bozkurt B, Kamat I, Hotez PJ. Myocarditis with COVID-19 mRNA vaccines. Circulation 2021;144:471-84.

69. Shay DK, Shimabukuro TT, DeStefano F. Myocarditis occurring after immunization with mRNA-based COVID-19 vaccines. JAMA Cardiol 2021 Jun 29. https://doi.org/10.1001/jamacardio.2021. 2821 [Epub ahead of print].

70. Wise J. Covid-19: should we be worried about reports of myocarditis and pericarditis after mRNA vaccines? BMJ 2021; 373:n1635.

71. O'Leary ST, Maldonado YA. Myocarditis after SARS-CoV-2 vaccination: true, true, and ... related? Pediatrics 2021;148: e2021052644.

72. Harris RJ, Hall JA, Zaidi A, Andrews NJ, Dunbar JK, Dabrera G. Effect of vaccination on household transmission of SARS-CoV-2 in England. N Engl J Med 2021;385:759-60.

73. Stefano GB. Historical insight into infections and disorders associated with neurological and psychiatric sequelae similar to long COVID. Med Sci Mon Int Med J Exp Clin Res 2021;27: e931447.

74. Hickie I, Davenport T, Wakefield D, Vollmer-Conna U, Cameron B, Vernon SD, et al. Post-infective and chronic fatigue syndromes precipitated by viral and non-viral pathogens: prospective cohort study. Br Med J 2006;333:575-8.

75. Buonsenso D, Munblit D, De Rose C, Sinatti D, Ricchiuto A, Carfi $A$, et al. Preliminary evidence on long COVID in children. Acta Paediatr 2021;110:2208-11.

76. Ludvigsson JF. Case report and systematic review suggest that children may experience similar long-term effects to adults after clinical COVID-19. Acta Paediatr 2021;110:914-21.

77. Ayoubkhani D. Prevalence of ongoing symptoms following coronavirus (COVID-19) infection in the UK : 1 April 2021. Office for national statistics:1-16. https://www.ons.gov.uk/ peoplepopulationandcommunity/healthandsocialcare/ conditionsanddiseases/bulletins/prevalenceofongoing symptomsfollowingcoronaviruscovid19infectionintheuk/ 2september2021 [Accessed 10 Sep 2021].

78. Molteni E, Sudre CH, Canas LS, Bhopal SS, Hughes RC, Antonelli $M$, et al. Illness duration and symptom profile in symptomatic UK school-aged children tested for SARS-CoV-2. Lancet Child Adolesc Health 2021;5:708-18.

79. Stephenson T, Stephenson T, Pereira SP, Shafran R, De Stavola B, Rojas N, et al. Long COVID - the physical and mental health of children and non-hospitalised young people 3 months after SARS-CoV-2 infection; a national matched cohort study (The CLoCk) study. Nat Portf 2021, in press. https://doi. org/10.21203/rs.3.rs-798316/v1.

80. Isba R, Edge R, Jenner R, Broughton E, Francis N, Butler J. Where have all the children gone? Decreases in paediatric emergency department attendances at the start of the COVID-19 pandemic of 2020. Arch Dis Child 2020;105:704.

81. Angoulvant F, Ouldali N, Yang DD, Filser M, Gajdos V, Rybak A, et al. Coronavirus disease 2019 pandemic: impact caused by school closure and national lockdown on pediatric visits and admissions for viral and nonviral infections - a time series analysis. Clin Infect Dis 2021;72:319-22. 
82. Finkelstein Y, Maguire B, Zemek R, Osmanlliu E, Kam AJ, Dixon A, et al. Effect of the COVID-19 pandemic on patient volumes, acuity, and outcomes in pediatric emergency departments: a nationwide study. Pediatr Emerg Care 2021;37:427-34.

83. Kruizinga $M D$, Peeters $D$, van Veen $M$, van Houten $M$, Wieringa J, Noordzij JG, et al. The impact of lockdown on pediatric ED visits and hospital admissions during the COVID19 pandemic: a multicenter analysis and review of the literature. Eur J Pediatr 2021;180:2271-9.

84. DeLaroche AM, Rodean J, Aronson PL, Fleegler EW, Florin TA, Goyal M, et al. Pediatric emergency department visits at US children's hospitals during the COVID-19 pandemic. Pediatrics 2021:147:e2020039628.

85. Haddadin Z, Schuster JE, Spieker AJ, Rahman H, Blozinski A, Stewart $L$, et al. Acute respiratory illnesses in children in the SARS-CoV-2 pandemic: prospective multicenter study. Pediatrics 2021;148:e2021051462.

86. Hills T, Kearns N, Kearns C, Beasley R. Influenza control during the COVID-19 pandemic. Lancet 2020;396:1633-4.

87. Britton PN, Hu N, Saravanos G, Shrapnel J, Davis J, Snelling T, et al. COVID-19 public health measures and respiratory syncytial virus. Lancet Child Adolesc Health 2020;4:e42-3.

88. Yeoh DK, Foley DA, Minney-Smith CA, Martin AC, MacE AO, Sikazwe CT, et al. Impact of coronavirus disease 2019 public health measures on detections of influenza and respiratory syncytial virus in children during the 2020 Australian winter. Clin Infect Dis 2021;72:2199-202.

89. Lazzerini M, Barbi E, Apicella A, Marchetti F, Cardinale F, Trobia G. Delayed access or provision of care in Italy resulting from fear of COVID-19. Lancet Child Adolesc Health 2020;4: e10-1.

90. Lynn RM, Avis JL, Lenton S, Amin-Chowdhury Z, Ladhani SN. Delayed access to care and late presentations in children during the COVID-19 pandemic: a snapshot survey of 4,075 paediatricians in the UK and Ireland. Arch Dis Child 2021;106:e8.

91. Roland D, Nijman RG, Ponmani C, Munro APS. Arriving late, delayed, or not at all-presentations to paediatric emergency departments during covid-19 pandemic. BMJ Opinion 2020. https://blogs.bmj.com/bmj/2020/08/15/arriving-latedelayed-or-not-at-all-presentations-to-paediatric-emergencydepartments-during-covid-19-pandemic/.

92. Honeyford K, Coughlan C, Nijman RG, Expert P, Burcea G, Maconochie I, et al. Changes in emergency department activity and the first covid-19 lockdown: a cross-sectional study. West J Emerg Med 2021;22:603-7.

93. Royal College of Paediatrics and Child Health. COVID-19 - resources for parents and carers. https://www.rcpch.ac.uk/resources/covid19-resources-parents-carers [Accessed 17 Jul 2021].

94. Roland D, Harwood R, Bishop N, Hargreaves D, Patel S, Sinha I. Children's emergency presentations during the COVID-19 pandemic. Lancet Child Adolesc Health 2020;4:e32-3.

95. Delgado-Miguel C, Munõz-Serrano AJ, Miguel-Ferrero M, De Ceano-Vivas M, Calvo C, Martínez L. Complicated acute appendicitis during COVID-19 pandemic: the hidden epidemic in children. Eur J Pediatr Surg 2021 Feb 22. https://doi.org/10. 1055/s-0041-1723992 [Epub ahead of print].

96. Gaitero Tristán J, Souto Romero H, Escalada Pellitero S, Espiñera $\mathrm{CR}$, Andina Martín D, Espinosa Góngora R, et al. Acute appendicitis in children during the COVID-19 pandemic: neither delayed diagnosis nor worse outcomes. Pediatr Emerg Care 2021;37:185-90.

97. Nelson CP, Kurtz MP, Logvinenko T, Venna A, McNamara ER. Timing and outcomes of testicular torsion during the COVID-19 crisis. J Pediatr Urol 2020;16:841. e1-e5.

98. Littman AR, Janssen KM, Tong L, Wu H, Wang MD, Blum E, et al. Did COVID-19 affect time to presentation in the setting of pediatric testicular torsion? Pediatr Emerg Care 2021;37:123-5.

99. Holzman SA, Ahn JJ, Baker Z, Chuang KW, Copp HL, Davidson J, et al. A multicenter study of acute testicular torsion in the time of COVID-19. J Pediatr Urol 2021 Mar 19. https://doi.org/10.1016/j. jpurol.2021.03.013 [Epub ahead of print].

100. Pogorelić Z, Milanović K, Veršić AB, Pasini M, Divković D, Pavlović 0 , et al. Is there an increased incidence of orchiectomy in pediatric patients with acute testicular torsion during COVID-19 pandemic?-A retrospective multicenter study. I Pediatr Urol 2021 May 1. https://doi.org/10.1016/j.jpurol.2021. 04.017 [Epub ahead of print].

101. Odd D, Stoianova S, Williams T, Sleap V, Blair P, Fleming P, et al. Child mortality in England during the COVID-19 pandemic. Arch Dis Child 2021;1-7. https://doi.org/10.1136/archdischild-2020320899.

102. Sharma S, Wong D, Schomberg J, Knudsen-Robbins C, Gibbs D, Berkowitz C, et al. COVID-19: differences in sentinel injury and child abuse reporting during a pandemic. Child Abuse Negl 2021;116:104990.

103. Chong SL, Soo JSL, Allen JC, Ganapathy S, Lee KP, Tyebally A, et al. Impact of COVID-19 on pediatric emergencies and hospitalizations in Singapore. BMC Pediatr 2020;20:562.

104. Swedo E, Idaikkadar N, Leemis R, Dias T, Radhakrishnan L, Stein $Z$, et al. Trends in U.S. Emergency Department visits related to suspected or confirmed child abuse and neglect among children and adolescents aged $<18$ years before and during the COVID-19 pandemic - United States, January 2019-September 2020. MMWR Morb Mortal Wkly Rep 2020;69:1841-7.

105. Sherman WF, Khadra HS, Kale NN, Wu VJ, Gladden PB, Lee OC. How did the number and type of injuries in patients presenting to a regional level I trauma center change during the COVID-19 pandemic with a stay-at-home order? Clin Orthop Relat Res 2021;479:266-75.

106. Bressan S, Gallo E, Tirelli F, Gregori D, Da Dalt L. Lockdown: more domestic accidents than COVID-19 in children. Arch Dis Child 2021;106:e3.

107. Orben A, Tomova L, Blakemore SJ. The effects of social deprivation on adolescent development and mental health. Lancet Child Adolesc Health 2020;4:634-40.

108. Newlove-Delgado T, McManus S, Sadler K, Thandi S, Vizard T, Cartwright $C$, et al. Child mental health in England before and during the COVID-19 lockdown. Lancet Psychiatr 2021;8: 353-4.

109. Ford T, John A, Gunnell D. Mental health of children and young people during pandemic. BMJ 2021;372:n614.

110. Lin JA, Hartman-Munick SM, Kells MR, Milliren CE, Slater WA, Woods ER, et al. The impact of the COVID-19 pandemic on the number of adolescents/young adults seeking eating disorderrelated care. J Adolesc Health 2021;69:660-3.

111. Unsworth R, Wallace S, Oliver NS, Yeung S, Kshirsagar A, Naidu $\mathrm{H}$, et al. New-onset type 1 diabetes in children during COVID-19: multicenter regional findings in the U.K. Diabetes Care 2020;43: e170-1. 
112. Salmi H, Heinonen $S$, Hästbacka J, Lääperi $M$, Rautiainen $P$, Miettinen PJ, et al. New-onset type 1 diabetes in Finnish children during the COVID-19 pandemic. Arch Dis Child 2021 May 27. https://doi.org/10.1136/archdischild-2020-321220 [Epub ahead of print].

113. Müller JA, Groß R, Conzelmann C, Krüger J, Merle U, Steinhart J, et al. SARS-CoV-2 infects and replicates in cells of the human endocrine and exocrine pancreas. Nat Metabol 2021;3: 149-65.

114. Fignani D, Licata G, Brusco N, Nigi L, Grieco GE, Marselli L, et al. SARS-CoV- 2 receptor angiotensin I-converting enzyme type 2 (ACE2) is expressed in human pancreatic $\beta$-cells and in the human pancreas microvasculature. Front Endocrinol 2020;11: 596898.

115. Hober D, Sauter P. Pathogenesis of type 1 diabetes mellitus: interplay between enterovirus and host. Nat Rev Endocrinol 2010;6:279-89.

116. Tittel SR, Rosenbauer J, Kamrath C, Ziegler J, Reschke F, Hammersen J, et al. Did the COVID-19 lockdown affect the incidence of pediatric type 1 diabetes in Germany? Diabetes Care 2020;43:e172-3.

117. Rabbone I, Schiaffini R, Cherubini V, Maffeis C, Scaramuzza A. Has covid-19 delayed the diagnosis and worsened the presentation of type 1 diabetes in children? Diabetes Care 2020;43:2870-2. 